\title{
S $\mathbf{\Omega}$ ПРОГРАММНЫЕ КОМПЛЕКСЫ \\ КОМПЬЮТЕРНОЙ РЕАЛИЗАЦИИ ЧИСЛЕННЫХ \\ МЕТОДОВ И МАТЕМАТИЧЕСКИХ МОДЕЛЕЙ \\ HA $И Х O C H O B E$
}

Idrisova S.R., Sultanova E.A.

\section{PROGNOSIS OF PROBABILITY OF FURTHER OPERATING AND ANALYSIS OF POSSIBLE MAINTAINABILITY OF BUILDINGS AND FACILITIES}

\begin{abstract}
The article deals with the basic of evaluation and indicators of operational safety of buildings and structures. The authors focuses on aspects such as the ability to predict the probability of further operation of buildings on the basis of data about the indicators of reliability, on the methods used in determining these indicators. The article studies the advantages and disadvantages of each method. Particular attention is paid to the urgency of the problem, identify its causes, among which the growth needs of many buildings in the reconstruction and rehabilitation, and the features of the building as complex objects. The paper describes the step by step construction of basic mathematical model, which is used in calculating the reliability of complex systems. Identify the most important problems encountered in the construction of the mathematical model, suggests some existing solutions to these problems. Evaluation of reliability of complex systems is carried out by methods involving the use of data failure and recovery elements obtained during the operation of systems. The scientific novelty is research of reliability, ensure uptime and minimal investment of time and money on technical maintenance and repairs of the building of the specified service life. Keywords:constructions, statistical characteristics, complex systems, maintainability of buildings, building reliability, mathematical model, methods of assessment, diagnostics, buildings exploitation, technical condition
\end{abstract}

Аннотация:Объектом исследования в данной работе являются основные методы оценки и расчета показателей эксплуатационной надежности зданий и сооружений. Авторы подробно рассматривают такие аспекты как возможность прогнозирования вероятности дальнейшейэксплуатации заний на основеданных о показателях их надежности, методы, применяемые при определении данных показателей. Изучаются основные преимущества и недостатки каждого из методов. Особое внимание уделяется актуальности проблемы, выявлению ее причин, среди которых рост потребности многих зданий в реконструкции и восстановлении, сложность зданий как объектов. В работе описывается пошаговое построение основной математической модели, которая используется при расчете надежности сложных систем. Выявляются наиболее важные проблемы, возникающие при 
построении этой математической модели, предлагаются некоторые существующие пути решения данных проблем. Оценка надежности сложных систем выполняется с помощью методов, связанных с использованием данных об отказах и восстановлениях элементов, полученных в прочессе эксплуатации систем. Научная новизна заключается в изучение надежности, m. е. обеспечение безотказной работы, а также минимальных затрат времени и средств на техническую эксплуатацию и ремонты здания за установленный срок службы.

Ключевые слова: статистические характеристики, сложные системы, ремонтопригодностьзданий, надежностьзданий, методы оченки, математическая модель, диагностика, эксплуатация зданий, строительные конструкции, техническое состояние

\section{Introduction}

The problem of assessment the possibility of extending the service life of buildings on the basis safety of structures is one of the topical problems of the modern state of many buildings exploitation.

Every year increases need renovation and recovery of the housing fund in the country. Since the obsolescence of buildings is added to the physical deterioration of structural components and engineering systems, which speeds up the overall aging process [7]. At present time, our country has accumulated quite large fund of buildings and structures. They are in completely different conditions, and this leads to the fact that the level of technical state also varies from good to emergency [6]. There is a problem of security in buildings. Safety of buildings and structures, extending their service life and lower operating costs are very important and topical problems, both for our country and for most other countries. The solution of all these problems is impossible without knowledge of the methods of evaluation and calculation of operational safety. Except, most modern buildings and structures are complex objects, different in specific personality. This adds significant challenges for the development of the theory of this calculation [8].

Redevelopment of premises carried out without the necessary need or without regard to the building project. The demolition of part of the load-bearing structures, and the load is unevenly distributed. This can lead to an emergency and the collapse of the building [9]. Avoiding such situations - a very important issue in our time.

In connection with the above factors, the issue of assessing the operational reliability of buildings is became especially important. Accordingly, it is important and necessary to study the complex methods for the diagnosis and assessment of residential buildings.

\section{Main part}

The object of research in this work is methods of evaluation and indicators of operational safety of buildings and structures.

As a rule, the reliability of the objects associated with failures of inadmissibility. That is they define it as the property of an object to safe a usable state for a certain time or a certain 
operating time. This reliability is closely associated with the various parties operating process. Regarded as a complex property, which is determined by such indicators as reliability, durability, maintainability and safety [4].

The main modern safety theory is a statistical approach to the study of events such as the failure and recovery $[5,10]$. For the application of methods of mathematical statistics, important moment is the possibility re-implementation of a random event in virtually identical conditions. Currently static data volume is small. Static data is characterized by the safety elements of the building. It is making difficult to determine their reliability parameters.

Another approach to the study of safety in the building structures it is the physical approach. In this case, the estimated reliability of the final element and it is possible with the help of some special instruments and methods to quantify and control the safety of building structures. The main disadvantage of a physical approach is that it does not allow to take into account the time factor. Which is fundamental when reliability calculations. Therefore, you need to know what types of failures are the greatest danger to the particular design and how soon normal design parameters of the work will begin to change, threatening failure. All should know when evaluating the safety of the element.

In assessing the reliability of any complex system, in particular, building structures and buildings used general mathematical model. The construction of the model consists of two steps and involves consideration of reliability as the probability of failure-free operation of the system for a concrete interval of time.

The first step is to build a model of a complex system partition into components. The second step is to specify the probability-statistical characteristics.

To describe the condition of the building at any time through the process $X(t)=\left(X_{1}(t), \ldots, X_{n}(t)\right)$. Each vector component can also be in different states. It can take on different values. For practical purposes, it suffices to assume that the number of these values is finite.

Let it $X$-is the set of all process values. It is called a phase space. This phase space is a finite set. This space consists of points $K_{1}, K_{2}, \ldots, K_{n}$. Let it $e_{i 1}, \ldots, e_{i k}$ - is possible value $i$ component of the vector. It means that it takes the value of the first coordinate $e 1, j 1$, etc . Next, a subset of the states $Q$ in the phase space $X$ is allocated. If $X(t)$ process was in $Q$ and then this suggests the possibility of a situation of failure. Pay attention all the above, you can find the reliability of the system $P(T)$ in time $T$ - it is probability that the process $X(t)$ in time $T$, coming from a fixed point, does not fall into the variety $Q$. That is $-«(T)=P\{X(t) \notin Q, t \in[0, T]\} »$.

Now we can consider the second step of constructing a mathematical model. It defines a probability and statistical characteristics of the process.

We introduce two assumptions:

1. That in a short time you can change coordinate of only one process.

2. That in a short time you can pass only in the neighboring state.

Let it $\mathrm{a}_{i}(x) D t$ - the probability that the system for the time $D$ t from the state $x=\left(x_{1}, \ldots, x_{n}\right)$ is transformed into a state $\tilde{x}=\left(\mathrm{x}_{1}, \ldots, x_{i+1}, x_{i+1}, \ldots, x_{n}\right)$. If we introduce a suggestion that the transitions from one state to a neighboring state depends only on the current state of the 
process, then the set of functions $\left\{\mathrm{a}_{i}(x), i=1,2, \ldots, n\right\}$ - is fully determines the probabilistic properties of the process.

However, there are two major problems. At first is the function obtain $\mathrm{a}_{i}(x)$ on the basis of experimental data. Secondly is determination of the probability $P(T)$, if the function $\mathrm{a}_{i}(x)(i=1, \ldots, n)$ has already been found.

Both of these problems are quite difficult mathematical problems. Which are related to the subject side of research. In our time, there are only solutions for some specific cases. Nevertheless, research and development of new methods are conducted. Moreover, there are ideas that allow to obtain an approximate value of $P(T)$. Calculation of constructions reliability is often based on the assumption that the uptime and recovery time elements have exponential probability distribution. This approach has a place to be. However, it does not cover all aspects of the problem being studied. Since the assumption of exponential physically means that we consider only the sudden failure, not associated with aging buildings. On the other hand, the interest of reconstructed buildings are just phasing. They are related to changes in the properties of materials in continuous operation, differential settlement of the building, the destruction of the brickwork, the loss of the bearing capacity of the slab - for corrosion of bearings, beams, etc. Some researchers believe that the timing of the visit in any state close to a normal distribution.

\section{Conclusion}

In this way, evaluation of reliability of complex systems is carried out by methods involving the use of data failure and recovery elements obtained during the operation of systems. In this case there are no general methods and versatile. In that, each building requires an individual review and assessment. Nevertheless, there are some ideas and approaches, the mathematical model used in the evaluation of complex systems. In this moment, researchers have different points of view. You can study them in more detail in [1]. However, it is clear that these issues require in-depth analysis and study.

\section{Библиография :}

1. Afanas'ev A.A., Matveev E.P. Rekonstrukcija zhilyh zdanij. Chast' 1. Tehnologii vosstanovlenija jekspluatacionnoj nadezhnosti zhilyh zdanij. [Technologies restore operational reliability of residential buildings]. Moscow, 2008. 479 p. [in Russian]

2. Filippov V.N., Trushkin 0.B. Komp'juternye tehnologii v nauke, obrazovanii i proizvodstve. [Computer technologies in science, education and industry]. Ufa, Ufa State Petroleum Technological University, 2011.

3. Filippova A.G., Belozyorov E.S., Filippov V.N., Belozyorov A.E., Sultanova E.A. Development method of designing a typed unified user interface. The electronic scientific journal «0il and Gas Business». 2011, no.4, pp.510-528.

4. Ostrejkovskij V.A. Teorija nadezhnosti. [Reliability theory]. Moscow, Vysshaja shkola Publ., 2008. 463 p. [in Russian]

5. Rogonskij V.A., Kostric A.I., Sherjakov V.F. Jekspluatacionnaja nadezhnost'zdanij. [Operational safety of buildings]. Leningrad, Strojizdat Publ., 1983. 280 p. [in Russian] 
6. Rojtman A.G. Preduprezhdenie avarij zhilyh zdanij. [Preventing accidents residential buildings]. Moscow, Strojizdat Publ., 1990. 240 p.[in Russian]

7. Sultanova E.A. Avtomatizacija metodov usilenija konstrukcij pri rekonstrukcii promyshlennyh zdanij i sooruzhenij. Sbornik: Informacionnye tehnologii. Problemy i reshenija. Materialy Mezhdunarodnoj nauchno-prakticheskoj konferencii: Dopolnitel'nyj sbornik. 2014. pp. 84-88. [in Russian]

8. Sultanova E.A., Rezjapova R.M., Chvanov A.P. Informacionnye tehnologii pri avtomatizacii vybora metoda rekonstrukcii zdanij i sooruzhenij. Sbornik: Informacionnye tehnologii. Problemy i reshenija. Materialy Mezhdunarodnoj nauchno-prakticheskoj konferencii: Dopolnitel'nyj sbornik. 2014. pp. 170-173. [in Russian]

9. Sultanova E.A., Filippov V.N. Avtomatizacija vybora metoda rekonstrukcii promyshlennyh zdanij i sooruzhenij. Programmnye sistemy i vychislitel'nye metody. 2013, no. 3., pp.233-244. [in Russian]

10. ruhanov. V.M. Kratkij kurs teorii i praktiki nadezhnosti slozhnyh sistem. [A short course on the theory and practice of reliability of complex systems]. Volgograd, 2007. 162 p. [in Russian]

\section{References:}

1. Afanas'ev A.A., Matveev E.P. Rekonstrukcija zhilyh zdanij. Chast' 1. Tehnologii vosstanovlenija jekspluatacionnoj nadezhnosti zhilyh zdanij. [Technologies restore operational reliability of residential buildings]. Moscow, 2008. 479 p. [in Russian]

2. Filippov V.N., Trushkin O.B. Komp'juternye tehnologii v nauke, obrazovanii i proizvodstve. [Computer technologies in science, education and industry]. Ufa, Ufa State Petroleum Technological University, 2011.

3. Filippova A.G., Belozyorov E.S., Filippov V.N., Belozyorov A.E., Sultanova E.A. Development method of designing a typed unified user interface. The electronic scientific journal «0il and Gas Business». 2011, no.4, pp.510-528.

4. Ostrejkovskij V.A. Teorija nadezhnosti. [Reliability theory]. Moscow, Vysshaja shkola Publ., 2008. 463 p. [in Russian]

5. Rogonskij V.A., Kostric A.I., Sherjakov V.F. Jekspluatacionnaja nadezhnost' zdanij. [Operational safety of buildings]. Leningrad, Strojizdat Publ., 1983. 280 p. [in Russian]

6. Rojtman A.G. Preduprezhdenie avarij zhilyh zdanij. [Preventing accidents residential buildings]. Moscow, Strojizdat Publ., 1990. 240 p.[in Russian]

7. Sultanova E.A. Avtomatizacija metodov usilenija konstrukcij pri rekonstrukcii promyshlennyh zdanij i sooruzhenij. Sbornik: Informacionnye tehnologii. Problemy i reshenija. Materialy Mezhdunarodnoj nauchno-prakticheskoj konferencii: Dopolnitel'nyj sbornik. 2014. pp. 84-88. [in Russian]

8. Sultanova E.A., Rezjapova R.M., Chvanov A.P. Informacionnye tehnologii pri avtomatizacii vybora metoda rekonstrukcii zdanij i sooruzhenij. Sbornik: Informacionnye tehnologii. Problemy i reshenija. Materialy Mezhdunarodnoj nauchno-prakticheskoj konferencii: Dopolnitel'nyj sbornik. 2014. pp. 170-173. [in Russian]

9. Sultanova E.A., Filippov V.N. Avtomatizacija vybora metoda rekonstrukcii promyshlennyh zdanij i sooruzhenij. Programmnye sistemy i vychislitel'nye metody. 2013, no. 3., pp.233-244. [in Russian]

10. Truhanov. V.M. Kratkij kurs teorii i praktiki nadezhnosti slozhnyh sistem. [A short course on the theory and practice of reliability of complex systems]. Volgograd, 2007. 162 p. [in Russian 